\title{
Role of Vegetarianism, Smoking, and Hydroxocobalamin in Optic Neuritis
}

\author{
N. H. WADIA, M. M. DESAI, E. V. QUADROS, D. K. DASTUR
}

British Medical fournal, 1972, 3, 264-267

\begin{abstract}
Summary
Only 20 patients with optic neuritis of unknown aetiology could be collected in Bombay over a period of two and a half years. Only six of them were smokers and only three (one a non-smoker) had bilateral centrocaecal scotomata similar to those found in tobacco amblyopia. In 11 untreated patients the serum vitamin $B_{12}$ and plasma thiocyanate levels were estimated and found to show no significant differences from those in normal control subjects. Treatment with hydroxocobalamin in the majority of cases and with cyanocobalamin, corticotrophin, or prednisolone in the rest showed equally good results; spontaneous improvement was seen in one case.

No significant role could be assigned to smoking (cyanide) or to vegetarianism in the production of optic neuritis in these patients; nor was there any evidence of depletion of total (cyanide-extracted) $B_{12}$ or of an increase in the proportion of non-cyanide-extracted $B_{12}$ in the serum.
\end{abstract}

\section{Introduction}

It was first suggested by Heaton et al. in 1958 that optic neuritis in tobacco smokers was related in some way to a disturbance of vitamin $B_{12}$ metabolism. In 13 patients with classical tobacco amblyopia they found the mean serum vitamin $B_{12}$ value to be well below that of control subjects. Similar findings were subsequently reported by Foulds et al. (1969). Smith (1961, 1962) suggested that this deficiency of $B_{12}$ was in the hydroxocobalamin form rather than the cyanocobalamin form. He maintained that in pipe smokers there was an excessive intake of cyanide which converted a good proportion of the hydroxocobalamin normally present into cyanocobalamin. He suggested that the difference between the values obtained on estimation of serum $B_{12}$ with and without the addition of a cyanide buffer represented the total amount of hydroxocobalamin in serum. He pointed out that this difference was much smaller in tobacco smokers with or without amblyopia than in normal subjects. He also stated that retrobulbar neuritis in patients with pernicious anaemia occurred only as a result of smoking and that this was due to "overt cyanide poisoning in the absence of sufficient specific antidote".

In addition, Freeman and Heaton (1961) found that retrobulbar neuritis in pernicious anaemia was far commoner in males than females, although pernicious anaemia itself had an equal sex incidence. This, they thought, was due to pipe or cigarette smoking. Wilson $(1963,1965)$ and Adams et al. (1966) postulated that Leber's heredofamilial optic atrophy was possibly due to some inborn error of cyanide metabolism. Wilson thought that the vast preponderance of males with this disease was due to the added effect of the cyanide in tobacco smoke.

J. J. Group of Hospitals, Bombay-8, India

N. H. WADIA, M.D., F.R.C.P., Head of Department of INeurology M. M. DESAI, M.B., B.S., Research Fellow

E. V. QUADROS, MSC, Research Assistant

D. K. DASTUR, M.D., M.R.C.PATH., Head of Neuropathology Unit
Similarly, it is known that intoxication acquired from the consumption of cassava, which is rich in cyanide, causes retrobulbar neuritis and ataxic-spastic syndromes in West Africa (Clark, 1936; Montgomery et al., 1964). Here again optic neuritis is most often seen in individuals who, through malnutrition, have relatively low (though physiological) serum $B_{12}$ concentrations which are insufficient to detoxicate the large quantities of cyanide taken in the food (Monekosso and Wilson, 1966; Osuntokun et al., 1969).

Thus various forms of optic neuritis have been suspected of being related to a disturbance of cyanide and $B_{12}$ metabolism. We argued that if optic neuritis is caused by "overt cyanide poisoning" from tobacco smoke "in the absence of sufficient specific antidote," then in India, where a large part of the often undernourished population is vegetarian by choice or financial necessity, the incidence of this "cyanogenic" optic neuritis would be higher than elsewhere; it would also be particularly high among vegetarian smokers, whose serum $B_{12}$ levels had been shown to be lower than those of other subgroups of the population (Dastur et al., 1972).

We therefore decided to estimate the blood $\mathbf{B}_{19}$, thiocyanate, and folate levels in patients with "idiopathic" optic neuritis and to compare the results with those obtained from normal controls (Dastur el al., 1972). Another objective of this investigation was to try the therapeutic effect of hydroxocobalamin on these patients in view of the preference for this form of vitamin $B_{12}$ in treatment expressed in published work (Smith, 1961, 1962; Chisholm et al., 1967; Foulds et al., 1968).

\section{Patients and Methods}

From 1968 onwards we made intensive efforts to collect cases of optic neuritis, preferably before treatment with the customary vitamin $B_{12}$ or $B$ complex. A personal request was made to the staff of the major ophthalmic hospitals of Bombay and to individual ophthalmologists and neurologists to allow us to examine and investigate their cases. We expected a large number of patients to be referred to us but, to our surprise, in spite of constant reminders and visits to hospitals we were able to collect only 20 cases of optic neuritis in two and a half years.

For the diagnosis of optic neuritis the presence of at least three of the following was required: (1) dimness or blurring of vision, (2) impaired visual acuity, (3) presence of scotomata, (4) fundal changes, and (5) pain in the eyeball. All cases in which there was a specific cause for the optic neuritis, such as syphilis, were excluded. As multiple sclerosis is rare in India "idiopathic" optic neuritis was not thought to be due to this disease unless the diagnosis was strongly suggested by the history or neurological signs.

Visual acuity was assessed with Snellen's test types, scotometry was performed with the Bjerrum screen, using different coloured test objects, and the visual fields were charted by perimetry. In addition to thorough neurological and systemic examinations a complete haemogram, blood V.D.R.L. and Wassermann tests, and examination of the cerebrospinal fluid were performed. In several cases the bone marrow was examined for evidence of megaloblastosis.

The serum $B_{18}$ and plasma thiocyanate levels were estimated in 14 patients and the serum folate level in 10 patients by the methods detailed in the accompanying paper (Dastur et al., 1972). 


\section{Results}

There were 12 males and 8 females, ranging in age from 13 to 48 years (mean 28.4 years). The disease was not confined to any one socioeconomic group. Thirteen ate a fairly good nonvegetarian diet, while seven were vegetarians, either by choice or necessity. Only one was a heavy smoker, having smoked an average of 30 cigarettes a day for several years. Five others smoked fewer than 25 beedis (very small local hand-rolled cigarillos) or 10 cigarettes a day. None were pipe smokers. There were nine non-vegetarian non-smokers, four nonvegetarian smokers, five vegetarian non-smokers, and only two vegetarian smokers. Four of the six smokers had drunk 200-400 $\mathrm{ml}$ of "country liquor" (a product of illicit distillation) daily for many years, while another, the heavy smoker, drank large quantities of whisky and rum. Analysis of samples of the "country" brew showed it to contain $37-49 \%$ ethyl alcohol, but no methyl alcohol, metals, chemicals, or other contaminants were detected.

The essential clinical findings in the 20 patients are given in Table I. Scotomata, which were found in only 10 patients,

TABLE I-Clinical Findings in 20 Patients with Optic Neuritis

\begin{tabular}{|c|c|c|c|c|c|c|c|}
\hline \multirow{2}{*}{$\begin{array}{l}\text { Case } \\
\text { No. }\end{array}$} & \multirow{2}{*}{$\begin{array}{l}\text { Sex } \\
\text { and } \\
\text { Age }\end{array}$} & \multirow{2}{*}{$\begin{array}{c}\text { Blurring } \\
\text { and } \\
\text { Dimness } \\
\text { of Vision }\end{array}$} & \multicolumn{2}{|c|}{$\begin{array}{c}\text { Impaired } \\
\text { Visual Acuity }\end{array}$} & \multirow{2}{*}{$\begin{array}{l}\text { Scoto- } \\
\text { mata }\end{array}$} & \multirow{2}{*}{$\begin{array}{c}\text { Fundal } \\
\text { Changes }\end{array}$} & \multirow{2}{*}{$\begin{array}{c}\text { Pain } \\
\text { in } \\
\text { Eyeball }\end{array}$} \\
\hline & & & Right & Left & & & \\
\hline \multicolumn{8}{|c|}{ Non-vegetarian Non-smokers } \\
\hline $\begin{array}{l}1 \\
2 \\
3 \\
4 \\
5 \\
6 \\
7 \\
8 \\
9\end{array}$ & $\begin{array}{l}\text { M. } 21 \\
\text { M. } 17 \\
\text { M. } 25 \\
\text { F. } 15 \\
\text { M. } 19 \\
\text { F. } 21 \\
\text { M. } 24 \\
\text { F. } 46 \\
\text { F. } 15\end{array}$ & $\begin{array}{l}+ \\
+ \\
+ \\
+ \\
+ \\
+ \\
+ \\
+ \\
+\end{array}$ & $\begin{array}{c}\text { F.C. } 6 \mathrm{ft} \\
6 / 36 \\
6 / 60 \\
6 / 9 \\
\text { No P.L. } \\
6 / 36 \\
6 / 12 \\
6 / 9 \\
\text { F.C. } 1.5 \mathrm{ft}\end{array}$ & $\begin{array}{l}6 / 6 \\
6 / 6 \\
6 / 6 \\
6 / 36 \\
6 / 18 \\
6 / 9 \\
6 / 6 \\
\text { F.C. } 6 \mathrm{ft} \\
\text { F.C. } 1.5 \mathrm{ft}\end{array}$ & 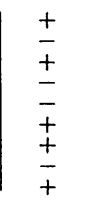 & $\begin{array}{l}- \\
+ \\
+ \\
+ \\
+ \\
+ \\
+ \\
+\end{array}$ & $\begin{array}{l} \pm \\
+ \\
+ \\
+ \\
\pm \\
\pm \\
+\end{array}$ \\
\hline \multicolumn{8}{|c|}{ Non-Vegetarian Smokers } \\
\hline $\begin{array}{l}10 \\
11 \\
12 \\
13\end{array}$ & $\begin{array}{l}\text { M. } 40 \\
\text { M. } 35 \\
\text { M. } 37 \\
\text { M. } 40\end{array}$ & $\begin{array}{l}+ \\
+ \\
+ \\
+\end{array}$ & $\begin{array}{l}\text { F.C. } 5 \mathrm{ft} \\
\text { F.C. } 3 \mathrm{ft} \\
\text { F.C. } 9 \mathrm{ft} \\
\quad 6 / 60\end{array}$ & $\begin{array}{c}\text { F.C. } 4 \mathrm{ft} \\
\text { F.C. } 3 \mathrm{ft} \\
6 / 60 \\
6 / 60\end{array}$ & $\begin{array}{l}\bar{t} \\
\dot{t}\end{array}$ & $\begin{array}{l}+ \\
+ \\
+\end{array}$ & $\begin{array}{l}\overline{-} \\
\bar{t}\end{array}$ \\
\hline \multicolumn{8}{|c|}{ Vegeiarian Non-Smokers } \\
\hline $\begin{array}{l}14 \\
15 \\
16 \\
17 \\
18\end{array}$ & $\begin{array}{l}\text { F. } 24 \\
\text { M. } 48 \\
\text { F. } 40 \\
\text { F. } 13 \\
\text { F. } 34\end{array}$ & $\begin{array}{l}+ \\
+ \\
+ \\
+ \\
+\end{array}$ & $\begin{array}{l}\text { F.C. }{ }_{\dot{P}}^{6 / 6} \mathrm{ft} \\
\text { M.B. } 2 \text { in } \\
6 / 6\end{array}$ & $\begin{array}{l}\quad 6 / 60 \\
\text { F.C. } 1 \mathrm{ft} \\
6 / 18 \\
\text { M.B. } 2 \text { in } \\
\text { F.C. } 6 \text { in }\end{array}$ & $\begin{array}{l} \pm \\
\frac{+}{+}\end{array}$ & $\begin{array}{l}- \\
+ \\
+ \\
+ \\
+\end{array}$ & $\begin{array}{l}- \\
= \\
=\end{array}$ \\
\hline \multicolumn{8}{|c|}{ Vegetarian Smokers } \\
\hline $\begin{array}{l}19 \\
20\end{array}$ & $\begin{array}{l}\text { M. } 30 \\
\text { M. } 25\end{array}$ & + & F.C. $3 \mathrm{ft}$ & $\begin{array}{l}6 / 36 \\
6 / 12\end{array}$ & $\overline{+}$ & + & $\overline{+}$ \\
\hline & & 20 & \multicolumn{2}{|c|}{20} & 10 & 16 & 8 \\
\hline
\end{tabular}

F.C. = Finger counting.

P.L. $=$ Perception of lig
M.B. = Moving body.

varied in size and shape and were central or centrocaecal. Nine of the 10 patients without scotomata showed the fundal changes of optic neuritis; the tenth (Case 13) had severely diminished visual acuity, pain in the eyeball, and pupils reacting very sluggishly to light. The fundus was abnormal in 16 patients, showing blurred margins (oedema) and pallor of the optic disc in four, blurred disc margins alone in five, and pallor alone (optic atrophy) in seven, mainly those in whom the optic neuritis was of long standing. In three of the four cases in which the optic disc was normal there was a central scotoma. In patients whose visual acuity permitted perimetric examination no peripheral constriction of the visual fields was found.

The present episode of optic neuritis was the first ever in $\mathbf{1 6}$ cases. The remaining four patients gave a history of a similar episode affecting either the same or the opposite eye or both eyes several months or years previously from which they had fully recovered. In Case 20 we observed two episodes of optic neuritis in the same eye at an interval of six months.

In 12 patients only one eye was affected, while eight, including five of the six smokers, were bilaterally affected. Three of these eight (Cases 9, 11, and 12) had central or centrocaecal scotomata to green, red, and white objects so that their optic neuritis was comparable to the tobacco amblyopia of Western pipe smokers. All three of them took a non-vegetarian diet with adequate calories; the two men smoked moderately and also drank the country liquor, but the girl neither smoked nor drank.

The total duration of the illness at the initial examination ranged from three days to six months, although all patients had developed maximum amblyopia within the previous few days. Apart from two patients who were seen two and six months respectively after the onset of symptoms, the average duration of illness was 12 days. With the exception of these symptoms and signs no abnormality was found in the nervous system. The haemogram, blood V.D.R.L. and Wassermann tests, and cerebrospinal fluid examination gave normal results. No evidence of megaloblastic anaemia was found in the patient whose bone marrow was examined.

\section{SERUM VITAMIN $B_{12}$}

The individual values for the 14 patients whose $B_{12}$ levels were determined are given in Table II. Three patients who had previously received injections of vitamin $B_{12}$ had very high serum $B_{12}$ levels, which have been excluded in the calculation of mean values (Tables III and IV).

\begin{tabular}{|c|c|c|c|c|c|}
\hline $\begin{array}{l}\text { Case } \\
\text { No. }\end{array}$ & $\begin{array}{l}\text { Total (CN- } \\
\text { extracted) } \\
\text { Serum } B_{12} \\
(\mathrm{pg} / \mathrm{ml})(\mathrm{A})\end{array}$ & $\begin{array}{l}\text { Non-CN- } \\
\text { extracted } \\
\text { Serum } B_{12} \\
(\mathrm{pg} / \mathrm{ml})(\mathrm{B})\end{array}$ & $\mathbf{B} / \mathbf{A} \times 100$ & $\begin{array}{c}\text { Plasma } \\
\text { Thiocyanate } \\
\text { ( } \mu \mathrm{mol} / \\
100 \mathrm{ml})\end{array}$ & $\begin{array}{c}\text { Serum } \\
\text { Folate } \\
(\mathrm{ng} / \mathrm{ml})\end{array}$ \\
\hline \multicolumn{6}{|c|}{ Non-vegetarian Non-smokers } \\
\hline \multirow[t]{2}{*}{$\begin{array}{l}3^{*} \\
5 \\
6 \\
7 \\
8 \\
9\end{array}$} & $\begin{array}{r}2,177 \\
280 \\
364 \\
273 \\
260 \\
245\end{array}$ & $\begin{array}{r}476 \\
91 \\
140 \\
154 \\
90 \\
70\end{array}$ & $\begin{array}{l}22 \cdot 0 \\
32 \cdot 0 \\
38 \cdot 0 \\
56 \cdot 0 \\
34 \cdot 0 \\
28 \cdot 0\end{array}$ & $\begin{array}{l}1.80 \\
1.80 \\
4.60 \\
3.00 \\
1.40 \\
1.40\end{array}$ & $\begin{array}{l}3 \cdot \overline{50} \\
\overline{5} \\
6 \cdot 25 \\
6.80\end{array}$ \\
\hline & \multicolumn{5}{|c|}{ Non-vegetarian Smokers } \\
\hline $\begin{array}{l}10^{*} \\
11^{*} \\
12 \\
13\end{array}$ & $\begin{array}{r}3,828 \\
850 \\
238 \\
161\end{array}$ & $\begin{array}{r}2,812 \\
619 \\
120 \\
63\end{array}$ & $\begin{array}{l}74 \cdot 0 \\
74 \cdot 0 \\
50 \cdot 0 \\
39 \cdot 0\end{array}$ & $\begin{array}{r}4 \cdot 00 \\
11 \cdot 00 \\
8 \cdot 80 \\
6 \cdot 30\end{array}$ & $\begin{array}{l}2 \cdot \overline{75} \\
9 \cdot 00 \\
2 \cdot 50\end{array}$ \\
\hline \multicolumn{6}{|c|}{ Vegetarian Non-smokers } \\
\hline $\begin{array}{l}17 \\
18\end{array}$ & $\begin{array}{l}630 \\
161\end{array}$ & $\begin{array}{l}315 \\
119\end{array}$ & $\begin{array}{l}50 \cdot 0 \\
74 \cdot 0\end{array}$ & $\begin{array}{l}1.00 \\
1.40\end{array}$ & $\begin{array}{l}4.00 \\
5.25\end{array}$ \\
\hline \multicolumn{6}{|c|}{ Vegetarian Smokers } \\
\hline $\begin{array}{l}19 \\
20\end{array}$ & $\begin{array}{l}532 \\
329\end{array}$ & $\begin{array}{l}147 \\
180\end{array}$ & $\begin{array}{r}28.0 \\
55.0\end{array}$ & $\begin{array}{r}13.70 \\
9.60\end{array}$ & $\begin{array}{l}1.90 \\
3.50\end{array}$ \\
\hline
\end{tabular}

*Patients with previous administration of vitamin $B_{12}$.

TABLB III-Serum Vitamin $B_{12}$, Thiocyanate, and Folate Levels in Four Groups of Patients (Mean \pm S.D.)

\begin{tabular}{|c|c|c|c|c|c|}
\hline $\begin{array}{c}\text { Group } \\
\text { (No. of cases) }\end{array}$ & $\begin{array}{c}\text { Total } \\
\text { [(CN- } \\
\text { extracted) } \\
\text { Serum B B18 } \\
\text { (pg/ml) } \\
\text { (A) }\end{array}$ & $\begin{array}{l}\text { Non- } \\
\text { CN - } \\
\text { extracted } \\
\text { Serum } \\
\text { B }_{12} \\
(\mathrm{pg} / \mathrm{ml}) \\
\text { (B) }\end{array}$ & $\mathrm{B} / \mathrm{A} \times 100$ & $\begin{array}{c}\text { Plasma } \\
\text { Thiocyanate } \\
\text { ( } \mu \mathrm{mol} / \\
100 \mathrm{ml})\end{array}$ & $\begin{array}{c}\text { Serum } \\
\text { Folate } \\
\text { (ng/ml) }\end{array}$ \\
\hline \multirow{2}{*}{$\begin{array}{l}\text { Non-smokers } \\
\text { (7) } \\
\text { Smokers (4) } \\
\text { Non-vegetar- } \\
\text { ians (7) } \\
\text { Vegetarians (4) }\end{array}$} & $\begin{array}{l}316 \pm 150 \\
315 \pm 160\end{array}$ & $\begin{array}{l}137 \pm 64 \\
128 \pm 50\end{array}$ & $\begin{array}{l}43 \pm 15 \cdot 8 \\
41 \pm 12 \cdot 0\end{array}$ & $\begin{array}{l}2.08 \pm 1.28 \\
9.60 \pm 3.07\end{array}$ & $\begin{array}{l}4.96 \pm 1.2 \\
4.22 \pm 2.81\end{array}$ \\
\hline & $\begin{array}{l}260 \pm 62 \\
413 \pm 210\end{array}$ & $\begin{array}{l}104 \pm 35 \\
190 \pm 87\end{array}$ & $\begin{array}{l}40 \pm 8.5 \\
46 \pm 19 \cdot 8\end{array}$ & $\begin{array}{l}3.90 \pm 2.82 \\
6.42 \pm 6.25\end{array}$ & $\begin{array}{l}5.41 \pm 2.59 \\
3.66 \pm 1.38\end{array}$ \\
\hline
\end{tabular}

TABLE IV-Serum Vitamin $B_{12}$ Thiocyanate, and Folate Levels in Control Subjects and Patients (Mean \pm S.D.)

\begin{tabular}{|c|c|c|c|c|c|}
\hline & $\begin{array}{c}\text { Total } \\
\text { (CN- } \\
\text { extracted } \\
\text { Serum } \\
\text { B }_{12} \\
\text { (pg/ml) } \\
\text { (A) }\end{array}$ & $\begin{array}{l}\text { Non- } \\
\text { CN- } \\
\text { extracted } \\
\text { Serum } \\
\text { B }_{12} \\
\text { (pg/ml) } \\
\text { (B) }\end{array}$ & $B / A \times 100$ & $\begin{array}{c}\text { Plasma } \\
\text { Thiocyanate } \\
\text { ( } \mu \mathrm{mol} / \\
100 \mathrm{ml})\end{array}$ & $\begin{array}{c}\text { Serum } \\
\text { Folate } \\
\text { (ng/ml) }\end{array}$ \\
\hline Controls (No.) & $292 \pm 169$ & $130 \pm(6 \overline{1}) 65$ & $45 \pm 11.5$ & $4.28 \underset{(63)}{+} 3.93$ & $5 \cdot 45 \pm 2.75$ \\
\hline Patients (No.) & $\begin{array}{c}316 \pm 146 \\
(11)\end{array}$ & ${ }_{(11)}^{135} 84$ & $43 \pm 14 \cdot 3$ & $\begin{array}{c}4 \cdot 80 \pm \frac{1}{(11)} 4 \cdot 40 \\
\text {. }\end{array}$ & $4.63 \frac{ \pm}{(9)} 2.23$ \\
\hline $\mathbf{P}$ & $\underset{(>0.1)}{\text { N.S. }}$ & & $\underset{(>0 \cdot 1)}{\text { N.S. }}$ & & \\
\hline
\end{tabular}


In the 11 patients who had not received $B_{12}$ injections the serum levels of total (cyanide-extracted) $B_{12}$ (value $A$ ) and non-cyanide-extracted $B_{12}$ (value $B$ ) were well within the range of values obtained from the 69 control subjects, and there was no statistically significant difference between the mean values of $\mathrm{A}$ for the patients $(316 \mathrm{pg} / \mathrm{ml})$ and the controls $(292 \mathrm{pg} / \mathrm{ml})$. The same was found to be true of $B$ expressed as a percentage of $A(B / A \times 100)$ (Table IV).

There was wide variation in the serum $B_{12}$ levels among individual patients in the four subgroups (Table II). The differences between subgroups previously observed in the control subjects were not seen in the patients; in fact, contrary to our expectations, the two vegetarian smokers had levels in the higher range of normal.

In Table III the mean values for smokers and non-smokers and for vegetarians and non-vegetarians among the patients are compared. The numbers were very small, however, and it was not possible to make a statistical evaluation of the differences between these subgroups or between the patients' values and those for the corresponding subgroups of control subjects (Dastur et al., 1972; Table II).

\section{PLASMA THIOCYANATE}

The plasma thiocyanate levels in the patients (Tables II and IV) were similar to those in the control subjects. As in the control series, the smokers showed a significantly higher mean value than the non-smokers (Table III). The highest values were seen in the two vegetarian smokers (Table II). The three patients who had previously received vitamin $B_{12}$ have been excluded from computation of the mean values for thiocyanate.

\section{SERUM FOLATE}

There were no striking differences in serum folate levels between the various subgroups of patients or between patients and control subjects.

\section{Treatment and Follow-up}

Sixteen patients were given intramuscular injections of hydroxocobalamin immediately after the diagnosis had been made and the investigations completed, and were given no other treatment. The first two were given $1,000 \mu \mathrm{g}$ daily. In one of them visual acuity improved from finger counting at $6 \mathrm{ft}$ to $6 / 36$ within 10 days; the other patient, seen six months after the onset of his visual symptoms, showed only slight improvement (from 6/36 to $6 / 24$ ) but refused to take more than three injections. The remaining 14 were given $500 \mu \mathrm{g}$ daily for varying periods to a total of 5-36 injections, and all but one showed considerable improvement in their visual acuity and clearance of scotomata.

The patient who did not improve (Case 16) presented with severe loss of vision of two months' duration. Case 12 showed clear improvement in visual acuity without any form of treatment; in spite of this he was given hydroxocobalamin and recovered fully.

Case 14 was treated with cyanocobalamin $500 \mu \mathrm{g}$ daily and also greatly improved. A patient who improved remarkably on hydroxocobalamin earlier (Case 20) had a recurrence of the optic neuritis. This time he was given cyanocobalamin injections and showed an equally good recovery. Case 17, who had bilateral optic neuritis with severe visual loss, was first given hydroxocobalamin for 10 days with only slight improvement; intramuscular corticotrophin was then administered with some further improvement; after this a combination of hydroxocobalamin and corticotrophin resulted in excellent recovery over a total period of two months. Case 4, who had improved on a previous occasion when treated elsewhere with Neurobion, a combination of cyanocobalamin, thiamine, and pyridoxine, was given prednisolone $60 \mathrm{mg}$ daily by mouth with full recovery after 13 days. Case 9 was given intramuscular injections of corticotrophin 80 to 40 units a day in reducing doses over a period of 25 days with good recovery.

\section{Discussion}

In a city with a population of over five million, only 20 cases of "idiopathic" optic neuritis could be collected over a period of two and a half years despite fairly good publicity. We had expected that if the effect of cyanide on serum $B_{12}$ was a significant factor in the pathogenesis of optic nerve disorders (Wilson et al., 1971), then a good proportion of the patients would show tobacco-amblyopia-like features and would be drawn from the large and undernourished vegetarian population of smokers.

Our findings were to the contrary-(1) all cases were of acute onset, and (2) only eight patients had bilateral disease, and of these only three had centrocaecal scotomata. Thus only in these last three (Cases 9, 11, and 12) was the condition comparable to tobacco amblyopia as reported from the West, and even in these the acute onset, and the spontaneous recovery in Case 12, may raise doubts about their authenticity. We cannot, therefore, justifiably regard any of our 20 cases as being similar to the original cases of Heaton et al. (1958). Heavy smoking among vegetarians in India is by no means uncommon, and hence one wonders what part smoking or a relatively low vitamin $B_{12}$ intake has to play in this variety of amblyopia.

Analysis of the $B_{12}$ levels in these 20 "idiopathic" cases also shows that no significance can be attached to the role of $B_{12}$ or smoking. None of the patients had a strikingly low serum total $B_{12}$ level (value $A$ ), nor was the mean level lower than in the control subjects. Furthermore, the four subgroups of patients did not differ clearly in respect of $A, B$, or $B / A \times 100$, unlike the control subjects, though this may well have been fortuitous because of the small number of patients in each subgroup. The plasma thiocyanate levels, however, were distinctly higher among smokers, whether vegetarians or non-vegetarians, in both patients and controls.

Although, as mentioned above, a number of types of optic neuritis have been linked together as resulting from cyanide intoxication and disturbed $B_{12}$ metabolism, the initial findings of low serum $B_{12}$ levels in the cyanogenic amblyopia of tobacco smokers and cassava eaters have not been fully supported. In fact, raised serum $B_{12}$ levels have actually been found in subjects eating cassava (Osuntokun et al., 1970) and in Leber's disease in non-smokers (Wilson et al., 1971).

Linnell et al. (1970) showed that methylcobalamin is the chief form of vitamin $B_{12}$ present in healthy people. They also found that the proportion of cyanocobalamin is very low even in the heaviest smokers. Wilson et al. (1971) showed increased serum cyanocobalamin levels in a variety of conditions like Leber's disease (and its carriers), dominantly inherited optic atrophy, tobacco amblyopia, and miscellaneous types of optic atrophy; in the first two conditions the level was raised even in nonsmokers. It has been pointed out by Linnell et al. (1969) and Matthews (1971) that abnormal levels of individual cobalamins can occur even in the presence of a normal total $B_{12}$ level, and we are inclined to agree with Matthews that an increase in the cyanocobalamin level may be an incidental reflection of impaired ability to metabolize cyanide. This might possibly be the case in the present patients; without the application of chromatobioautographic methods of estimation it must remain a matter for conjecture. Thus the exact role of vegetarianism, smoking and vitamin $B_{12}$ in "idiopathic" optic neuritis of various kinds, as also in tobacco amblyopia, remains unclear.

Victor (1970) rejected the idea that tobacco, and hence cyanide, plays any part in so-called tobacco amblyopia. He pointed out that both Carroll (1947) and De Grosz (1949) reported 
amblyopia similar to tobacco amblyopia occurring as a result of malnourishment only, without any intake of tobacco. He also maintained that chronic, sustained, low-level cyanide intoxication, an experimental situation similar to that produced by smoking, does not cause any neurological effects. He has also challenged the exclusive role of $B_{12}$, pointing out that deficiency of vitamins other than $B_{12}$ can cause a tobacco-amblyopia-like syndrome which can be cured by an adequate diet supplemented by brewer's yeast. Also, Calhoun (1918) described similar paracentral as well as central scotomata in patients with pellegra which could be cured by the administration of nicotinic acid. Some claim has also been made for riboflavin deficiency as a factor in such amblyopias. While deficiency of vitamin $B_{1}$ may play a part in the causation of tobacco amblyopia, it is likely that other B vitamins and perhaps other nutritional factors produce the same pathological effect.

Whereas we found striking improvement with hydroxocobalamin in many of our cases, equal improvement was seen in others with cyanocobalamin, corticotrophin, or prednisolone, or spontaneously. Spontaneous recovery in optic neuritis is well known (Traquair, 1957; Walsh, 1957). Of the three patients with bilateral centrocaecal scotomata simulating tobacco amblyopia, one improved on corticotrophin alone, while another started improving spontaneously before hydroxocobalamin was given.

Hence two conclusions can justifiably be drawn from our cases. (1) That tobacco amblyopia is rare in this part of India in spite of a large population of vegetarian smokers. This is the more interesting in view of the fact that in the control series vegetarian smokers had high plasma thiocyanate levels and the lowest serum $B_{12}$ levels in the population. (2) That smoking, vegetarianism, and vitamin $B_{12}$ (either as hydroxocobalamin or as cyanocobalamin) play no part in the pathogenesis of isolated "idiopathic" optic neuritis as seen in our patients.

We are grateful for a grant from Glaxo Laboratories (India) Ltd., and for grant No. 01-011-1 from the National Institute of
Health of the U.S. Department of Health, Education, and Welfare. We thank the consultants of the Haji Bachooali Eye Hospital and the Kamatipura Eye Hospital for permission to study and treat patients under their care, and the drug controller and the chemical analyst, Government of Maharashtra, for analysis of liquor samples.

\section{References}

Adams, J. H., Blackwood, W., and Wilson, J. (1966). Brain, 89, 15.

Calhoun, F. P. (1918). American fournal of Ophthalmology, 1, 834.

Carroll, F. D. (1947). American fournal of Ophthalmology, 30,172

Chisholm, I. A., Bronte-Stewart, J., and Foulds, W. S. (1967). Lancet, 2, 450.

Clark, A. J. (1936). Journal of Tropical Medicine and Hygiene, 39, 269.

Dastur, D. K., Quadros, E. V., Wadia, N. H., Desai, M. M., and Bharucha, E. P. (1972). British Medical Journal, 3, 260.

De Grosz, S. (1949). Ophthalmologica, 118, 764.

De Grosz, S. (1949). Ophthalmologica, 118, 764. (1968). Lancet, 1, 896.
.

Foulds, W. S., Chisholm, I. A., Bronte-Stewart, J., and Wilson, T. M. (1969). British fournal of Ophthalmology, 53, 393 .

Freeman, A. G., and Heaton, J. M. (1961). Lancet, 1, 908.

Heaton, J. M., McCormick, A. J. A., and Freeman, A. G. (1958). Lancet, 2, 286.

Linnell, J. C., Hoffbrand, A. V., Peters, T. J., and Matthews, D. M. (1969). fournal of Clinical Pathology, 22, 742.

Linnell, J. C., Hussein, H. A.-A., and Matthews, D. M. (1970). Fournal of Clinical Pathology, 23, 820.

Matthews, D. M. (1971). British Medical fournal, 3, 659.

Maneksosso, G. L., and Wilson, J. (1966). Lancet, 1, 1062.

Monekosso, G. L., and Wilson, J. (1966). Lancet, 1, 1062. McMenemey, W.' Cruickshank, E. K.' (1964). Brain, 87, 425.

Osuntokun, B. O., Langman, M. J. S., Wilson, J., and Aladetoyinbo, A. (1970). Fournal of Neurology, Neurosurgery and Psychiatry, 33, 663.

Osuntokun, B. O., Monekosso, G. L., and Wilson, J. (1969). British Medical fournal, $1,547$.

Smith, A. D. M. (1961). Lancet, 1, 1001.

Smith, A. D. M. (1962). British Medical fournal, 1, 1965.

Traquair, H. M. (1957). In Traquair's Clinical Perimetry, ed. C. I. Scott, 7th edn., p. 173. London, Kimpton.

Victor, M. (1970). In Miami Neuro-ophthalmology Symposium, ed. G. L. Smith, vol. 5, p. 33. Florida, Huffman.

Walsh, F. B. (1957). In Clinical Neuro-ophthalmology, p. 309. Baltimore, Williams and Wilkins.

Wilson, J. (1963). Brain, 86, 347.

Wilson, J. (1963). Brain, 86, 347. $29,505$.

Wilson, J., Linnell, J. C., and Matthews, D. M. (1971). Lancet, 1, 259.

\title{
Hormonal Responses to Synthetic Luteinizing Hormone and Follicle Stimulating Hormone-Releasing Hormone in Man
}

\author{
G. M. BESSER, A. S. MCNEILLY, D. C. ANDERSON, J. C. MARSHALL, P. HARSOULIS, \\ R. HALL, B. J. ORMSTON, L. ALEXANDER, W. P. COLLINS
}

British Medical fournal, 1972, 3, 267-271

\section{Summary}

The effects of the gonadotrophin-releasing hormone, synthetic decapeptide luteinizing hormone/follicle stimu-

\section{St. Bartholomew's Hospital, London E.C.1}

G. M. BESSER, M.D., M.R.C.P., Senior Lecturer in Endocrinology

A. S. MCNEILIY, B.SC., PH.D., Research Lecturer.

Royal Postgraduate Medical School, London W.12

J. C. MARSHALL, B.SC., M.R.C.P., Research Fellow, Department of P. HARSOULIS, M.D., Research Fellow

Department of Medicine, Royal Victoria Infirmary, Newcastle upon Tyne 1

R. HALL, M.D., F.R.C.P., Professor of Medicine

B. J. ORMSTÖN, M.B., B.S., Research Fellow

L. ALEXANDER, M.B., M.R.C.P., Senior Medical Registrar

Department of Biochemical Endocrinology, Chelsea Hospital for Women, London W.16

W. P. COLLINS, B.Sc., PH.D., Principal Biochemist lating hormone-releasing hormone (LH/FSH-RH), have been studied in 18 normal men and five women in the follicular phase of their menstrual cycle. Rapid and dosedependent (25 to $100 \mu \mathrm{g}$ ) increases in serum immunoreactive LH were seen, which reached a peak 20 to 30 minutes after a rapid intravenous injection. Similar but much smaller increases in serum immunoreactive FSH were seen. These conclusions have been validated by using two different immunoassay systems for each hormone. The LH/FSH-RH therefore causes both LH and FSH release in man as in animals but does not affect growth hormone, thyrotrophin, or ACTH. The gonadotrophin responses were the same in the women as in the men but were insufficient in the men to cause statistically significant changes in the serum levels of the gonadal steroid hormones, testosterone or oestradiol, or in their precursors $17 \alpha$-hydroxyprogesterone or progesterone. In the women, however, there was a rise in oestradiol after the 100- $\mu \mathrm{g}$ doses. The use of LH/FSH-RH will provide an important test to define the level of the lesion in hypogonadal patients and also should be valuable in the treatment of some types of male and female in- 